\title{
Alkaline phosphatase, cytokeratin 7, cytokeratin 8 in the diagnosis of primary lung adenocarcinoma from 148 pleura fluids specimens
}

\author{
Oğuztüzün Serpil'1, Atay Meral², Özhavzalı Müzeyyen ${ }^{3}$, Temelli Özlem¹, \\ Yırtıcı Ümit ${ }^{1}$, Türk Mustafa ${ }^{1}$, Atay Ziya ${ }^{2}$ \\ ${ }^{1}$ Department of Biology, Kırlkkale University, 71450 Yahşihan-Kırlkkale, Turkey \\ ${ }^{2}$ Hannover Cytology Clinic, Hannover, Germany \\ ${ }^{3}$ Department of Mathematics, Krrlkkale University, 71450 Yahşihan-Krrlkkale, Turkey
}

\begin{abstract}
Adenocarcinomas are the most common cause of malignancy in pleura fluids. Usual primary sites include the lung, breast, gastrointestinal tract, and genitourinary tracts. Predicting the site of origin of an adenocarcinoma can be difficult due to overlapping morphologic characteristics. We investigated the use of alkaline phosphatase (AP), Cytokeratin7 (CK7) Cytokeratin8 (CK8) to distinguish adenocarcinomas of lung in 148 body cavity fluid samples. Overall results for primary lung adenocarcinomas, demonstrated CK8 reactivity in $106(72 \%)$ of 148 cases. 95 primary lung carcinoma samples $(65 \%)$ were positive for CK 7 . AP was expressed in $81 \%$ of primary lung adenocarcinomas. Positive immunoreactivity for AP was characterized by a red, diffusely apical cytoplasmic staining in tumor cells that ocurred singly or in groups. There was a significant difference between AP, CK 7 and CK 8 expressions in primary lung adenocarcinomas $(\mathrm{P}=0.02$; Chisquared test). The sensitivity of AP, CK8, CK7 as a marker for primary lung adenocarcinomas were $82 \%, 72 \%, 64 \%$, respectively. Thus the AP positive staining largely confirmed the cytologic diagnosis of lung adenocarcinoma.
\end{abstract}

Key words: lung adenocarcinoma, alkaline phosphatase, cytokeratine 7 , cytokeratine 8 , immunocytochemistry, body cavity fluids

\section{Introduction}

The incidence of lung cancer in the United States has been steadily increasing in recent years, and lung cancer now ranks as the primary cause of death from cancer in American men [1]. Non-small cell carcinomas account for about $85 \%$ of all lung cancers. About $60 \%$ of lung cancers are adenocarcinomas, and about $26 \%$ are squamous cell carcinomas [2]. The proportion of adenocarcinomas has been increasing recently, and the percentage of woman with adenocarcinoma has also been rising [3].

Adenocarcinomas are the most common epithelial malignancies found in body cavity fluids. Common primary sites include the lung, breast, gastrointestinal tract, and genitourinary tract. Identification of the spe-

Correspondence: Serpil Oğuztüzün, Kırikkale Universitesi, Biyoloji Bölümü 71450 Yahşihan-Kırikkale, Turkey; tel.: (+90535) 4642445, fax.: (+90318) 3572461,

(+90318) 3572923, e-mail: soguztuzun@yahoo.com cific site of origin may carry important prognostic as well as therapeutic implications. However, determination of the primary site of adenocarcinoma based on cytomorphology alone can be a challenging task. Tissue specific immunohistochemical markers offer an attractive means for confirming metastatic disease in patients with known primary tumors and may assist in identifying the primary sites in patients with adenocarcinomas of unknown origin.

Blobel et al. [4] showed that alveolar cells of human lung contained cytokeratin $(\mathrm{CK})$ polypeptides typical of simple epithelia (CK7, 8, 18, and 19). Basal cells of the bronchial epithelium, on the other hand, contained CK5 and small amounts of CK6. Consequently, it has been also found "simple-epitheliumtype" cytokeratins in all adenocarcinomas and later also in squamous cell carcinomas [5]. CK8 is the most widely expressed cytokeratin in various epithelial cells and cancer cells among at least 21 related cytokeratins [6]. One study has demonstrated that CK8 is found in the serum of a subgroup of patients with non-small cell 
lung carcinomas [7]. CK7, a neutral-basic type II cytokeratin found in adenocarcinomas of breast and lung, among others [8-10].

Alkaline phosphatase (AP) isoenzymes are widely distributed in various organs, and activity and/or AP identification in bronchial fluid is a marker of lung carcinoma and metastases [11-13]. Human APs are reportedly encoded by four different genes: a gene fort he liver/bone/kidney isozyme (tissue-nonspecific type, TNAP), a gene for the adult intestinal isozyme (IAP) a gene for the placental (PLAP), a gene for the germ cell isozyme (placental-like AP or GCAP [14]. TNAP is the predominant AP isozyme in the lung, where it is largely produced by type II pneumocytes [15], but trace amounts of PLAP are also expressed by type I pneumocytes [16].

Muensh et al. [17] have found that AP is elevated in $23 \%$ of 286 patients suffering from various neoplasms. AP was elevated most commonly in cases of colorectal cancer (54\%), ovarian cancer (44\%) and lung cancer $(40 \%)$. It seems that expression of certain cytokeratins (CK7, CK8) and AP may be useful in the diagnosis of primary lung adenocarcinomas. This study was undertaken to evaluate the clinical utility of CK7, CK8 and $\mathrm{AP}$ in the diagnosis of primary lung adenocarcinoma in body cavity fluids specimens.

\section{Materials and methods}

Cases. The cytological files of the Hannover Cytopathology Institute were reviewed between 6 January 2005 and 21 February 2007. The 148 pleural fluids were collected from 148 patients who were diagnosed with adenocarcinoma. Medical records were reviewed to verify that the cases were of primary lung origin and did not represent metastatic disease from primary tumors at other sites. The selection of patients was restricted to include those in whom the primary site of origin for the carcinoma was confirmed based on clinical findings $(n=148)$. Slides that were stained previously by routine Giemsa methods were retrieved for each patient. The diagnosis of adenocarcinoma based on cytomorphology was confirmed. Classic cytologic features of malignancy included three-dimensional aggregates comprised of cells with increased nuclear-to-cytoplasmic ratios, irregular nuclear membranes, course chromatin, large irregular nucleoli and finely vacuolated cytoplasm. The sensitivity of CK7, CK8 and AP in body cavity fluid samples for primary lung adenocarcinomas were calculated.

Immunocytochemistry procedure. Cytological smears were prepared by standard cytologic method. The slides were hydrated in decreasing ethanol solutions. Endogenous peroxidase was blocked with hydrogen peroxidase for 3 minutes. The slides were rinsed in water, were incubated with the biotin blocking system (Dako) prior to application of the primary antibody. The CK7 and CK8 monoclonal antibodies were used at a dilution of 1:100 and incubated with the samples for 1 hour. The slides were then rinsed in buffer and incubated for 25 minutes with the linking solution (LSAB+ kit; Dako; biotinylated antimouse, antirabbit, and antigoat). This was followed by a rinse in buffer and incubation with streptavidin peroksidase for 25 minutes. After rinsing in buffer, the slides were submerged in AEC for 5 minutes. The slides were counterstined with Mayer's hematoxilen. The slides were then dehydrated through gradient alcohols, cleared in xylene, and coverslipped. Only cytoplasmic staining was regarded as a positive result. The intensity of staining was graded on a 0 (absent), 1+ (weak), 2+ (moderate), and 3+ (strong). All material was evaluated blindly by two observers. Statistical analysis was performed using the chisquared test and the orthagonal test. The chi-square test was used to determine statistical significance.

Enzyme cytochemistry. For detection of AP activity, 17.5 mg naptithyle phosphate sodium salt monohydrate were dissolved in $35 \mathrm{ml}$ o. 1 mole veronalnatrium buffer $(\mathrm{pH}=9.4)$ and mixed with $35 \mathrm{mg}$ variamine blue B salt. The mixture was freshly prepared before use. We incubated cells for 60 minutes at $4{ }^{\circ} \mathrm{C}$ and counterstained with Mayer's hemalum solution for $4 \mathrm{~min}$. Then the slides were mounted with glycerol gelatin. Cytoplasmic staining of tumor cell was considered positive.

\section{Results}

The results of AP, CK7, CK8 immunostaining of lung adenocarcinomas in 148 pleura fluids are shown in Table 1 . AP was expressed in $81 \%$ of primary lung adenocarcinomas. Positive immunoreactivity for AP was characterized by a red diffusely cytoplasmic staining in tumor cells that ocurred singly or in groups. AP showed cytoplasmic staining in adenocarcinoma cells (Fig. 1). 27 of 148 fluids from adenocarcinoma of lung origin were negative for AP. 95 $(65 \%)$ primary lung carcinoma samples were positive for CK7 (Fig.2a, b).

Overall results for primary lung adenocarcinomas demonstrated CK8 reactivity in $106(72 \%)$ of 148 cases (Fig.3). Staining intensity was moderate in most primary $(1+, 31$ cases; $2+, 52$ cases; $3+, 23$ cases) lung adenocarcinomas.

Table 1 has showed the staining patterns of primary lung adenocarcinomas from pleural effusions for AP, CK7 and CK8. For all primary lung adenocarcinomas studied, $121(81 \%)$ of cases exhibited AP, $95(65 \%)$ of cases exhibited CK7, 106 (72\%) of cases exhibited CK8 immunostaining.

There was a significant difference between AP, CK7 and CK8 expressions in primary lung adenocarcinomas $(\mathrm{P}=0.02$; Chi-squared test $)$. The statistical values are given in Table 2 . The sensitivity of AP, CK7 and CK8 as a marker for primary lung adenocarcinoma were $82 \%, 64 \%$, and $72 \%$ respectively. AP had the highest sensitivity of the primary lung adenocarcinoma studied, with a sensitivity of $82 \%$.

\section{Discussion}

Adenocarcinoma is the most common cause of malignancy in body cavity fluids. Usual primary sites include the lung, breast, gastrointestinal tract, and genitourinary tracts. Predicting the site of origin of an adenocarcinoma can be difficult due to overlapping morphologic characteristics. Lung is a common primary 
Table 1. Staining intensity of AP, CK7 and CK8 in primary lung adenocarcinomas from pleural effusions.

\begin{tabular}{|l|c|c|c|c|c|c|}
\hline \multicolumn{1}{|c|}{ Tumor Markers } & $\mathrm{n}$ & $\begin{array}{c}\text { Negative n } \\
(\%)\end{array}$ & $\begin{array}{c}\text { Positive } \mathrm{n} \\
(\%)\end{array}$ & $1+(\%)$ & $2+(\%)$ & $3+\%)$ \\
\hline Alkaline Phosphatase & 148 & $27(18)$ & $121(81)$ & $31(21)$ & $58(39)$ & $32(21)$ \\
\hline Cytokeratin 7 & 148 & $53(35)$ & $95(65)$ & $26(18)$ & $36(24)$ & $33(22)$ \\
\hline Cytokeratin 8 & 148 & $42(28)$ & $106(72)$ & $31(20)$ & $52(35)$ & $23(15)$ \\
\hline
\end{tabular}

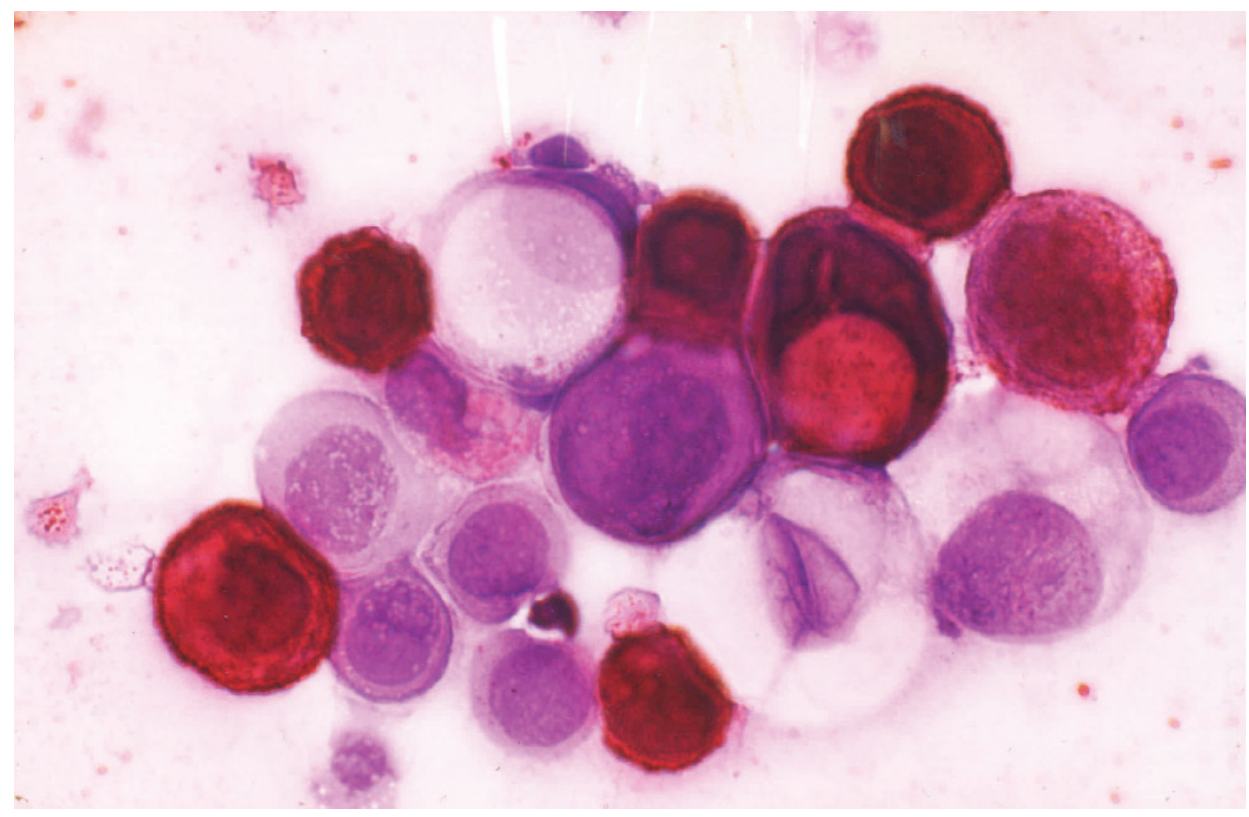

Figure 1. Cytochemical staining of primary lung adenocarcinoma with alkaline phosphatase. Couterstained with hematoxylin (pleura, original magnification $\mathrm{x} 600$ )

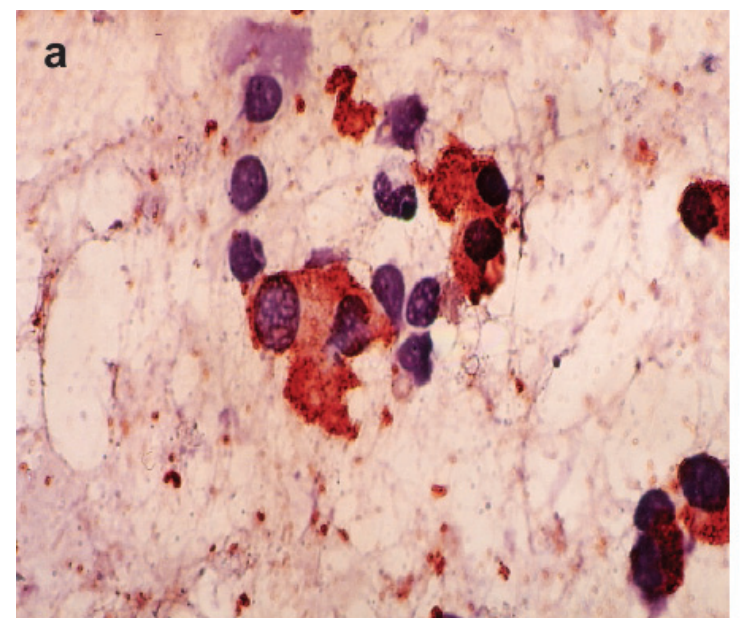

b

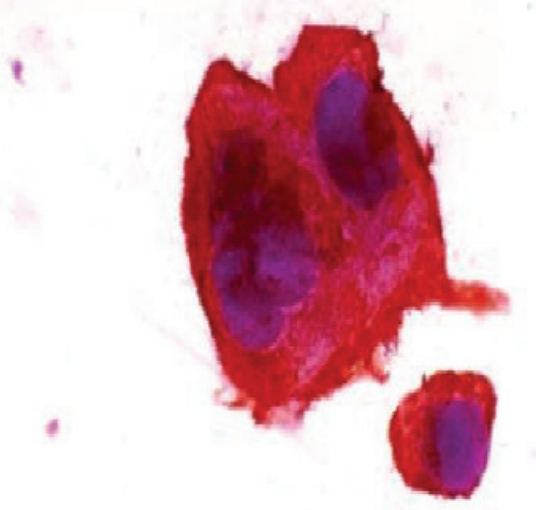

Figures 2a,b. Two primary lung adenocarcinoma samples show intense cytoplasmic staining with cytokeratin 7 ((a) Pleura, immunoperoxidase-hematoxylin, x200) and (b) Pleura, immunoperoxidase-hematoxylin, x400)

site for adenocarcinomas in body cavity fluids [18-20]. We investigated the use of AP, CK7 CK8 to distinguish adenocarcinomas of lung in 148 pleura fluids.

Organ specific markers using immunohistochemistry offer an attractive means for subclassifying adenocarcinomas according to primary site. CK7 and CK8 are tissue specific protein expressed selectively in the epithelial cells of the lung [21].

Cytokeratins, belonging to the intermediate filament (IF) protein family, are particularly useful tools in oncology diagnostics. At present, more than 20 different cytokeratins have been identified, of which 
Table 2. Sensitivity values of AP, CK7 and CK8 staining in primary lung adenocarcinomas.

\begin{tabular}{|c|c|c|}
\hline $\begin{array}{c}\text { Tumor } \\
\text { Markers }\end{array}$ & $\begin{array}{c}\text { Sensitivity } \\
=\mathrm{TP} /(\mathrm{TP}+\mathrm{FN})^{*} 100\end{array}$ & $\begin{array}{c}\text { Sensitivity } \\
\text { (orthagonal comparative } \\
\text { method) }\end{array}$ \\
\hline $\mathrm{AP}$ & $81.6^{*}$ & $0.608^{*}$ \\
\hline $\mathrm{CK} 7$ & $64.19^{* *}$ & $0.466^{* *}$ \\
\hline $\mathrm{CK} 8$ & 71.62 & 0.527 \\
\hline
\end{tabular}

cytokeratins 8, 18, and 19 are the most abundant in simple epithelial cells. Upon release from proliferating or apoptotic cells, cytokeratins provide useful markers for epithelial malignancies. Previous examination has demonstrated CK 7 and CK 8 positivity in the vast majority of lung adenocarcinomas studied [7,22]. Using commercially available monoclonal antibody for CK8, we demonstrated a sensitivity of $72 \%$ for lung adenocarcinomas. 95 primary lung carcinoma samples $(65 \%)$ were positive for CK 7 . The sensitivity of CK7 as a marker for primary lung adenocarcinomas was $65 \%$.

Human alkaline phosphatase isoenzymes have been classified electrophoretically and immunohistochemically into four major groups: hepatic, intestinal, bone and placental [23]. Placental alkaline phosphatase (PLAP) levels are elevated during pregnancy and in cigarette smokers. However, in non-pregnant women and non-smokers, PLAP activity is very low, compromising less than $1 \%$ of the total alkaline phosphatase activity [17,24].

Following the discovery by Fishman et al. [14] that PLAP elevation is associated with bronchogenic carcinoma, many other studies have confirmed that this isoenzyme is ectopically produced by various neoplasms [25-27]. Muensh et al. [17] have found, that PLAP is elevated in $23 \%$ of 286 patients suffering from various neoplasms. PLAP was elevated most commonly in cases of colorectal cancer (54\%), ovarian cancer (44\%) and lung cancer (40\%). Other studies have confirmed raised serum concentrations of this alkaline phosphatase isoenzyme in $15-64 \%$ of patients with ovarian cancer [28-31]. One study showed that almost all ovarian cancer tissues contained PLAP to some extend, however there was a low frequency of detectable serum levels of PLAP, especially in the early stages of the disease [29]. In this study, AP was expressed in $81 \%$ of primary lung adenocarcinomas. Positive immunoreactivity for AP was characterized by a red diffusely cytoplasmic staining in tumor cells that ocurred singly or in groups. The specificity and positive predictive values of the AP antibody for the adenocarcinomas of lung origin in our series were both $81 \%$.

Staining for AP activity is a rapid and simple test, which does not require any special equipment. When

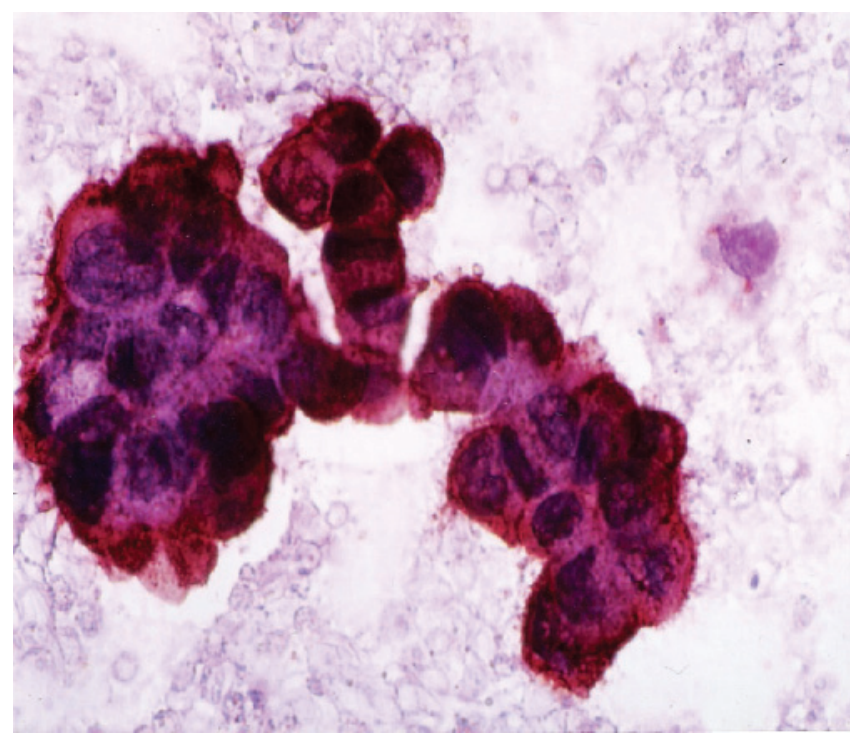

Figure 3. Immunocytochemical staining for cytokeratin 8 in a group of lung adenocarcinoma cells (Pleura, immunoperoxidasehematoxylin, $\mathrm{x} 400$ )

used carefully and in conjunction with additional testing such as cytology, detection of AP activity appears to be a useful tool in the diagnosis of primary lung adenocarcinom. Generally, the cytologic and clinical features of the tumors can assist in diagnosis. In addition, detection of AP activity only improves the ability of the clinician and pathologist to appropriately diagnose primary adenocarcinoma of lung.

This application of the AP marker onto cytological slides of lung adenocarcinoma can be very helpful in daily clinical cytology practice. The staining technique is simple, and the AP yields highly sensitive results. A positive reaction for AP may serve to confirm the spread of a known primary lung tumor, establish the recurrence of a previously treated adenocarcinoma of the lung, or identify the lung as a possible source of malignancy in a patient with an unknown primary site. In this study, AP was expressed in $81 \%$ of primary lung adenocarcinomas. Positive immunoreactivity for AP was characterized by a red diffusely cytoplasmic staining in tumor cells that ocurred singly or in groups. The specificity and positive predictive values of the AP antibody for the adenocarcinomas of lung origin in our series were both $81 \% .27$ of 148 fluids from adenocarcinoma of lung origin were negative for AP.

The histologic distinction between primary pulmonary adenocarcinomas and adenocarcinomas metastases to the lung can be a difficult task, with significant clinical ramifications. In this regard, immunohistochemical evaluation of CK7 and CK8 and AP expression patterns has been a useful method of accurately classifying these entities [32-36].

Our findings have confirmed the results of other studies with regard to the high frequency and intensity of CK7, CK8 and AP expressions in lung adenocarci- 
nomas [37-40]. The sensitivity of AP, CK8, CK7 as a marker for primary lung adenocarcinomas were $81 \%, 72 \%, 65 \%$, respectively. Thus the AP positive staining largely confirmed the cytologic diagnosis of lung adenocarcinoma.

\section{References}

[1] Levi F, Lucchini F, Negri E, La Vecchia C. World wide patterns of cancer mortality, 1990-1994. Eur J Cancer Prev. 1999;8:381-400.

[ 2] Kuroishi T, Hirose K, Tominaga S, Ogawa H, Tajima K. Prediction of future cancer mortality in Japan. Jpn J Clin Oncol. 1992;22:365-369.

[ 3] Travis WD, Luvin J, Ries L, Devesa S. United States lung carcinoma incidence trends: declining for most histologic types among males, increasing among females. Cancer. 1996;15: 2464-2470.

[ 4] Blobel GA, Moll R, Franke WW, et al. Cytokeratins in normal lung and lung carcinomas. I.Adenocarcinomas, squamous cell carcinomas and cultered cell lines. Virchows Arch. 1984;45:407-429.

[ 5] Blobel GA, Gould VE, Moll R, et al. Coexpression of neurocrine markers and epithelial cytoskeletal proteins in bronchopulmonary neuroendocrine neoplasms. Lab Invest. 1985; 52:39-51.

[6] Moll R, Franke WW, Schiller DL. The catalog of human cytokeratins:patterns of expression in normal epithelia, tumors and cultured cells. J Cell Sci. 1081;50:45.

[ 7] Boers JLV, Ramaekers FCS, Klein RM, et al: Cytokeratins in different types of human lung cancer as monitored by chain specific monoclonal antibodies. Cancer Res. 1988;48:3221-9.

[ 8] Pendleton N, Myskow MW, Gren JA. Expression of cytokeratins, involucrin and peanut agglutinin binding lectin in resected non-small cell lung carcinomas. Br J Cancer. 1992; 65:37.

[9] Pendleton N, Occleston NL, Walshaw MJ, et al. Simple cytokeratins in the serum of patients with lung cancer:relationship to cell death: Eur J Cancer. 1994;30A:93-96.

[10] Hendrix MJ, Seftor EA, Chu YW, Trevor KT, Sftor RE. Role of intermediate filaments in migration, invasion and metastasis: Cancer Metastasis Rev. 1996;15:507-525.

[11] Hoshino T, kumasaka K, Kawano K, Koyama I, Arai-Fujimori Y, Yamagishi F, sakagishi Y, Komoda T. Abnormal alkaline phosphatase of hepatic type in cerebrospinal fluid of a patient with intracranial metastasis from lung cancer. $J$ Clin Pathol. 1993;46:1059-1061.

[12] Miyanaga M, Sugimoto H, Komoda T, Nosjean O, Honma K, Nemoto K, Sato T. A variant alkaline phosphatase detected in a patient with lung cancer. Enzyme Protein. 1996;49:313-320.

[13] Cobben NA, Drent M, Lacobs JA, Schmitz MP, Mulder PG, Henderson RF, et al. Relationship between enzymatic markers of pulmonary cell damage and cellular profile: a study in bronchioalveolar lavage fluid. Exp Lung Res. 1999;25:99-111.

[14] Fishman WH: alkaline phosphatase isoenzymes: recent progress. Clin Biochem. 1990;23:99-104.

[15] Edelson JD, Shannon JM, Mason RJ. Alkaline phosphatase: a marker of alveolar type II cell differentiation. Am Rev Respir Dis. 1988;138:1268-1275.

[16] Nouwen EJ, Buyssens N, De Broe ME. Heat-stable alkaline phosphatase as marker for human and monkey-type-I pneumocytes. Cell Tissue Res. 1990;260:321-335.

[17] Muensh HA, Maslow WC, Azama F, Bertrand M, Dehwurst P, Harman B. Placental-like alkaline phosphatase. Cancer. 1986;58:1689-94.
[18] Fluids. In: DeMay RM, editor: The art and science of cytopathology, $1^{\text {st }}$ edition. Chicago: ASCP Press; 1996.

[19] Murphy WM, Ng ABP. Determination of primary site by examination of cancer cells in body fluids. Am J Clin Pathol. 1972;58:479-488.

[20] Sears D, Hajdu SI. The cytologic diagnosis of malignant neoplasms in pleural and peritoneal effusions. Acta Cytol. 1987; 31:85-97.

[21] Shitara K, Fujiwara K, Kusano A, Yamaguchi K, Yoshida H, Sato $\mathrm{S}$ and Hanai N. Application of anti lung adenocarcinoma monoclonal antibody recognizing cytokeratin-like cytoplasmic antigen for tumor diagnosis. Anticancer Res. 1992;12: 1121-1130.

[22] Sack MJ, Roberts SA. Cytokeratins 20 and 7 in the differential diagnosis of metastatic carcinoma in cytologic specimens. Diagnostic Cytopathol. 1997;16:132-136.

[23] Millan JL, Fishman WH. Bilogoy of human alkaline phosphatase with special reference to cancer. Crit Rew Clin Lab Sci. 1995;32(1):1-39.

[24] Tonik SE,Ortmeyer AE, Shindelman JE, Susman HH. Elevation of serum placental alkaline phosphatase in cigarette smokers. Int J Cancer. 1983;31:51-3.

[25] DeBore ME, Pollet DE. Multicenter evaluation of human placental alkaline phosphatase as a possible tumor-associated antigen in serum. Clin Chem. 1988;34:1995-9.

[26] Vergote I, Onsrud M, Nustad K. Placental alkaline phosphatase as a tumor marker in ovarian cancer. Obstet Gynecol. 1987;69:228-32.

[27] Fisken J, Leonard RCF, Shaw G, Bowman A, Roulston JE, Serum placental-like alkaline phosphatase (PLAP): a novel combined enzyme linked immunoassay for monitoring ovarian cancer. J Clin Pathol. 1989;42:40-5.

[28] Pollet DE, Nouwen EJ, Schelstraete JB, Renard J, Van-de Voodre A, De-Bore ME. Enzyme-antigen immunoassay for hPLAP in serum and tissue extracts and its application as a tumor marker. Clin Chim Acta. 1985;31:41-51.

[29] Mano H, Furuhashi Y, Morikawa Y, Hattori S-E, Gto S, Tomoda Y. Radioimmunoassay of placental alkaline phosphatase in ovarian cancer sera and tissue. Obstet Gynecol. 1986;68:759-64.

[30] Doellgast GJ, Homesley HD. Placental-type alkaline phosphatase in ovarian cancer fluids and tissues. Obstet Gynecol. 1984;63:324-9.

[31] Iino N, Matsunaga T, Harada T, Igarashi S, Koyama I, Komoda T. Comparative characterization of pulmonary surfactant aggregates and alkaline phosphatase isoenzymes in human lung carcinoma tissue. Cell Tissue Res. 2007;328:355-36.

[32] Chu PG, Wu E, Weiss LM. Cytokeratin 7 and cytokeratin 20 expression in epithelial neoplasms: a survey of 435 cases. Mod Pathol. 2000;13:962-72.

[33] Tan JY, Gurdip S, Greco MA, Ballard H, Wieczorek R. Villin, cytokeratin 7 and cytokeratin 20 expression in pulmonary adenocarcinoma with ultrastructural evidence of microvilli with rootlets. Hum Pathol. 1998;29:390-6.

[34] Wang NP, Zee S, Zarbo RJ, Bacchi CE, Gown AM. Coordinate expression of cytokeratins 7 and 20 defines unique subsets of carcinomas. Appl Immunohistochem. 1995;3:99107.

[35] Miettinen M. Keratin 20. Immunohistochemical marker for gastrointestinal, urothelial, and Merkel cell carcinoma. Mod Pathol. 1995;8:384-8.

[36] Loy TS, Calaluce RD. Utility of cytokeratin immunostaining in separating pulmonary adenocarcinomas from colonic adenocarcinomas. Am J Clin Pathol. 1994;102:764-7.

[37] Lau SK, Desrochers MJ, Luthringer DJ. Expression of thyroid transcription factor-1, cytokeratin 7 , and cytokeratine 20 in bronchioalveolar carcinomas: an immunohistochemical evaluation of 67 cases. Mod Pathol. 2002;15:538-542. 
[38] Ramackers F, Van Nickerk C, Poels L et al. Use of monoclonal antibodies to keratin 7 in the differential diagnosis of adenocarcinomas. Am J. Pathol. 1990;136:641-655.

[39] Chieng DC, Cangiarella JF, Zakowski MF, Goswami S, Cohen JM, Yee HT. Use of thyroid transcription factor 1, PE10 , and cytokeratins 7 and 20 in discriminating between primary lung carcinomas and metastic lesions in fine-needle aspiration biopsy specimens. Cancer. 2001;93:330-336.
[40] Leroy X, Copin MC, Boman F, Gosselin B. Les cytokeratines 7 at 20: aide au typage des tumeurs. Ann Pathol. 1998;18: 103-109.

Submitted: 5 May 2008 Accepted after reviews: 9 November 2008 